\title{
Analisis Kejadian EI Nino dan Dampaknya Terhadap Musim Tanam dan Produktivitas Kacang Tanah (Arachis hypogaea L) di Pulau Kei Kecil Kabupaten Maluku Tenggara
}

\author{
Analysis of El Nino Events and Their Impact on the Growing Season and Productivity of Peanut \\ (Arachis hypogaea L) in Kei Kecil Island, Maluku Tenggara Regency
}

\section{Esterlina Kelbulan, Semuel Laimeheriwa* dan Jacob R. Patty}

\author{
Jurusan Budidaya Pertanian, Fakultas Pertanian, Universitas Pattimura, Jl. Ir. M. Putuhena, Kampus Poka, Ambon \\ 97233, Indonesia \\ *E-mail Penulis Korespondensi: laimeheriwasamuel@yahoo.co.id
}

\begin{abstract}
Climate change has an impact that includes extreme climate events such as El Nino. Experience in recent decades has shown that the El Nino climate anomaly has caused prolonged droughts. Peanut are susceptible to drought in part or all of its growth phases due to below-normal rainfall. This study aimed to describe the occurrence of extreme El-Nino rainfall on Kei Kecil Island, Maluku Province, and how much the El-Nino events affected the planting season and peanut production on Kei Kecil Island. This was carried out using the algebraic average technique for calculating the average (normal) rainfall and the FAO (1978) method for determining the growing season. The variables observed were rainfall data and peanut plant productivity data. Data were analyzed using simple regression analysis. The results of the study showed that the El Nino phenomenon generally took place in the period from April to November; mostly starting in April, May, June and September, October and November. Drought events on Kei Kecil Island did not always coincide with El Nino events, and El Nino events did not always cause drought or rainfall below normal. In 1993, 2003, 2007, and 2012 the amount of rainfall on Kei Kecil Island was below normal ( $<2,308$ mm per year) but these years were not recorded as El Nino years. Whereas, 1994, 2009, 2014, and 2018 were recorded as El Nino years but did not cause drought or rainfall under normal conditions on Kei Kecil Island. During the last 30 years, this incident occurred 3 times, i.e. in 1991, 1997, and 2015. The results of the analysis of the growing season showed that the planting season on Kei Kecil Island under conditions of average (normal) rainfall lasted for 289 days or 9 months 16 days (November 1 to August 16). Meanwhile, the growing season when extreme El Nino rainfall occurred, lasted for 201 days or 6 months 20 days (November 1 to May 20). This indicated that when El Nino occurred on Kei Kecil Island, there was a shift in the growing season (ending sooner). The results of the regression analysis illustrated that the increase of the value of rainfall would increase the productivity of peanut crop.
\end{abstract}

Keywords: El Nino phenomenon, growing season, peanut, productivity, rainfall

\begin{abstract}
ABSTRAK
Perubahan iklim berdampak di antaranya terhadap kejadian iklim ekstrim seperti El Nino. Pengalaman dalam beberapa dekade terakhir ini menunjukkan bahwa anomali iklim El Nino telah menyebabkan kekeringan berkepanjangan. Kacang tanah rentan oleh deraan kekeringan pada sebagian ataupun seluruh fase pertumbuhannya akibat curah hujan yang di bawah normal. Penelitian ini bertujuan untuk mempelajari kejadian curah hujan ekstrim El-Nino di Pulau Kei Kecil, Provinsi Maluku, dan seberapa besar kejadian El-Nino mempengaruhi musim tanam dan produksi kacang tanah di Pulau Kei Kecil. Ini dilaksanakan dengan menggunakan metode teknik rata-rata aljabar untuk perhitungan curah hujan rata-rata (normal) dan metode FAO (1978) untuk penentuan musim tanam. Variabel yang diamati adalah data curah hujan dan data produktifitas tanaman kacang tanah. Data dianalisis menggunakan analisis regresi sederhana. Hasil penelitian menunjukkan fenomena El Nino umumnya berlangsung dalam periode April hingga November; terbanyak mulai bulan April, Mei, Juni dan September, Oktober dan November. Kejadian kekeringan di Pulau Kei Kecil tidak selalu bersamaan dengan kejadian El Nino, dan kejadian El Nino tidak selalu menyebabkan kekeringan atau curah hujan di bawah normal. Pada tahun 1993, 2003, 2007, dan 2012 jumlah curah hujan di Pulau Kei Kecil berada pada kondisi di bawah normal $(<2.308 \mathrm{~mm}$ per btahun) tetapi tahun-tahun tersebut tidak tercatat sebagai tahun-tahun El Nino. Sementara itu, tahun 1994, 2009, 2014, dan 2018 tercatat sebagai tahun-tahun El Nino tetapi tidak menyebabkan kekeringan atau curah hujan di bawah kondisi normalnya di Pulau Kei Kecil. Selama periode 30 tahun terakhir kejadian ini berlangsung selama 3 kali, yaitu pada tahun 1991, 1997, dan 2015. Hasil analisis musim tanam menunjukkan bahwa musim tanam di Pulau Kei Kecil pada kondisi curah hujan rata-rata (normal) berlangsung selama 289 hari (1 November sampai dengan 16 Agustus; 9 bulan 16 hari). Sedangkan musim tanam ketika curah hujan ekstrim El Nino berlangsung selama 201 hari (1 November sampai dengan 20 Mei). Hal ini mengindikasikan bahwa ketika El Nino berlangsung di Pulau Kei Kecil, akan terjadi pergeseran musim tanam (berakhir lebih cepat). Hasil analisis regresi menggambarkan bahwa penigkatan nilai curah hujan akan menigkatkan produktivitas tanaman kacang tanah.
\end{abstract}

Kata kunci: curah hujan, fenomena El Nino, kacang tanah, musim tanam, produktivitas 


\section{PENDAHULUAN}

Kacang tanah (Arachis hypogaea L.) merupakan salah satu sumber pangan potensial dalam mendukung ketahanan pangan nasional dan pendapatan petani. Tanaman ini biasanya ditanam petani di lahan kering yang kebutuhan airnya hanya bergantung pada hujan yang jatuh; baik selama musim hujan maupun selama musim kemarau Kacang tanah akan rentan oleh deraan kekeringan baik pada sebagian ataupun seluruh fase pertumbuhannya karena curah hujan yang rendah (di bawah normal).

Pemanasan global dan perubahan iklim yang menyertainya berdampak di antaranya terhadap kejadian iklim ekstrim seperti El Nino (curah hujan rendah; di bawah normal dan/atau kekeringan yang panjang). Pengalaman dalam beberapa dekade terakhir ini menunjukkan bahwa anomali iklim El Nino telah menyebabkan kekeringan berkepanjangan pada berbagai wilayah di Indonesia. Kejadian El Nino di antaranya berdampak pada berkurangnya ketersediaan air tanah yang berdampak lanjut terhadap pendeknya musim tanam karena musim kering yang lebih panjang dari biasanya (berlangsung lebih awal dan/atau berakhir lebih lambat). Pendeknya musim tanam akan mengurangi intensitas tanam atau luas tanam dan panen berkurang yang akhirnya bermuara pada rendahnya produksi tanaman bahkan gagal panen.

Hasil penelitian di wilayah Maluku oleh Nangimah et al. (2018) dan Laimeheriwa et al. (2019) menunjukkan bahwa ketika kejadian El Nino berlangsung, panjang musim tanam akan berkurang dari kondisi normalnya, yaitu dari 8 bulan menjadi 5 bulan di Daerah Waeapo Pulau Buru dan dari 12 bulan menjadi 6 bulan di Pulau Ambon. Pendeknya musim tanam tersebut tentunya berpengaruh terhadap berkurangnya luas tanam atau luas panen dan produksi tanaman pangan (termasuk kacang tanah) per tahunnya. Las (2006) melaporkan bahwa kejadian El Nino selama periode 19682000 menyebabkan penuruan luas panen dan produktivitas tanaman pangan di berbagai daerah di Indonesia. Rata-rata penurunan luas panen palawija (jagung, ubi kayu, ubi jalar, kacang tanah dan kedelai) adalah sebesar 0,25\% hingga $11,25 \%$ dengan rata-rata penurunan produktivitas sebesar $0,07 \%$ hingga $0,99 \%$.

Pernyataan berbagai ahli dan banyak literatur mengemukakan bahwa wilayah yang paling rentan terhadap perubahan iklim seperti kejadian EL Nino adalah pulau-pulau kecil dan relatif berbeda antar daerah/pulau dengan pola hujan terntentu; monsunal, lokal, atau ekuatorial (Sitaniapessy, 2002; Laimeheriwa, 2014). Irianto dan Suciantini (2006) mengemukakan bahwa berkaitan dengan anomali iklim El Nino, wilayah dengan pola monsunal merupakan wilayah yang paling terpengaruh kejadian anomali iklim tersebut.

Pulau Kei Kecil merupakan salah satu pulau kecil (luas < $2.000 \mathrm{~km} 2$ ) pada gugusan kepulauan Kei di wilayah Provinsi Maluku yang memiliki pola hujan monsunal (Laimeheriwa, 2014). Pulau ini tentunya sangat rentan terhadap kejadian iklim ekstrim El Nino. Komoditas kacang tanah merupakan salah satu komoditas tanaman pangan yang diusahakan petani di Kabupaten Maluku Tenggara termasuk Pulau Kei Kecil. Menurut data BPS (2019), dalam periode 2014-2018, rata-rata luas areal tanam kacang-kacangan (kacang tanah, kacang hijau dan kedelai) di wilayah ini sebesar 389 ha; dimana dominannya sebesar 51\% atau 198 ha merupakan areal pertanaman kacang tanah. Kacang tanah ini merupakan komoditas yang diandalkan petani sebagai sumber pendapatan keluarga maupun sebagai bahan pangan. Implikasinya, sejauhmana kejadian El Nino yang berdampak pada penurunan produksi dan produktivitas tanaman pangan, khusunya kacang tanah, perlu dikaji sehingga diperoleh informasi yang bermanfaat dalam menyusun strategi antisipasi dan adaptasi dampak negatif tersebut.

Penelitian ini bertujuan untuk: 1) mendeskripsikan tahun-tahun kejadian curah hujan ekstrim El Nino serta intensitas dan frekuensinya, 2) menentukan musim tanam ketika kejadian curah hujan ekstrim El Nino dan 3) menganalisis hubungan antara curah hujan dan produktivitas kacang tanah di Pulau Keci Kecil.

\section{BAHAN DAN METODE}

\section{Tempat dan Waktu Penelitian}

Penelitian ini dilaksanakan di Pulau Kei Kecil, Kabupaten Maluku Tenggara, Provinsi Maluku, dan berlangsung selama dua bulan, yaitu Agustus sampai dengan September 2019.

\section{Bahan dan Alat}

Bahan yang digunakan dalam penelitian ini berupa data iklim, data pertanian (terutama produksi kacang tanah), dan data penunjang. Alat yang digunakan adalah: program MS Word dan MS Excel 2013 (Microsoft, Redmond, Washington, AS), Program CROPWAT 8.0 (The Land and Water Development Division, FAO, Rome), Program Minitab (State College, Pennsylvania, AS), laptop dan alat tulis menulis.

\section{Metode Penelitian}

Tahap-tahap penelitian utama adalah sebagai berikut: 
1. Pemgumpulan data meliputi: data iklim yang diperoleh dari Stasiun Meteorologi Dumatubun Tual berupa data curah hujan periode pengamatan 30 tahun terakhir (1989 -2008); data unsur iklim lainnya (suhu udara, kelembaban udara, penyinaran matahari, dan angin) periode pengamatan 15 tahun terakhir (2004-2018), Data luas areal tanam, luas panen dan produksi dan produktivitas kacang tanah 5 tahun terakhir (2014-2018), hasil wawancara dengan petani kacang tanah di Pulau Kei Kecil menggunakan kuisioner serta data BPS.

2. Analisis data meliputi: analisis data curah hujan menggunakan teknik rata-rata aljabar, analisis musim tanam menggunakan metode FAO (1978) dan analisis hubungan curah hujan dengan produktivitas tanaman menggunakan persamaan regresi sederhana.

\section{HASIL DAN PEMBAHASAN}

\section{Distrbusi Tahunan Curah Hujan Pulau Kei Kecil}

Selama periode 30 tahun periode 1989-2018 telah terjadi penyimpangan curah hujan di atas kondisi normalnya sebanyak 8 kali, yaitu pada tahun 1998, 1999, 2000, 2001, 2010, 2013, dan 2016. Di sisi lain, penyimpangan curah hujan di bawah kondisi normal terjadi sebanyak 10 kali, yaitu pada tahun 1991, 1993, 1997, 2002, 2003, 2004, 2006, 2007, 2012, dan 2015. Dengan demikian, dalam periode 30 tahun tersebut, telah terjadi sebanyak $60 \%$ penyimpangan curah hujan dari kondisi normalnya, sementara curah hujan berada pada selang normalnya sebanyak $40 \%$ (12 tahun), yaitu tahun 1989, 1990, 1992, 1994, 1995, 1996, 2005, 2008, 2009, 2014, 2017 dan 2018 (Gambar 1).

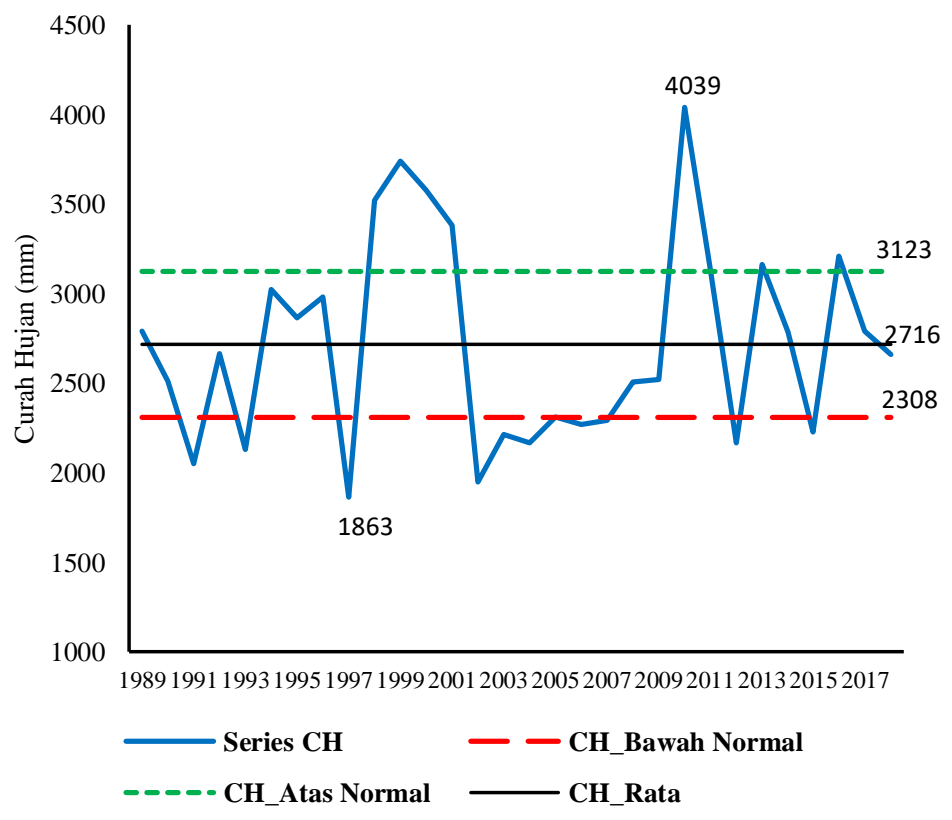

Gambar 1. Distribusi curah hujan $(\mathrm{CH})$ tahunan Pulau Kei Kecil

\section{Curah Hujan Ekstrem El Nino di Pulau Kei Kecil}

Berdasarkan nilai Oceanic Nino Index (ONI) periode 30 tahun terakhir (1989-2018; NOAA, 2019) yang bersumber dari pengukuran suhu muka laut (sea surface temperature, SST) pada wilayah Nino 3.4 di Samudera Pasifik, diperoleh gambaran bahwa sejak tahun 1989 hingga 2018 kejadian El-Nino di Indonesia berlangsung sebanyak 10 kali dengan frekuensi 1-5 tahun sekali atau rata-rata 3 tahun sekali. Sementara itu, berdasarkan data time series curah hujan 30 tahun periode 1989-2018 di Pulau Kei Kecil, dari 10 kali kejadian penyimpangan curah hujan yang kurang dari kondisi normalnya, 6 kali $(60 \%)$ diantaranya bertepatan dengan kejadian El-Nino di wilayah Indonesia yang tercatat pada region Nino 3.4, yaitu pada tahun 1991, 1997, 2002, 2004, 2006, dan 2015, dengan frekuensi 2-9 tahun sekali atau rata-rata 5 tahun sekali.

Fenomena El Nino umumnya berlangsung dalam periode April-November; terbanyak mulai dalam bulan April, Mei, Juni dan September, Oktober, November. Tingkat perubahan curah hujan sangat tergantung pada intensitas El Nino. Laimeheriwa et al. (2019) menyatakan bahwa tidak seluruh wilayah Indonesia dipengaruhi langsung oleh fenomena ini. Hal ini karena adanya perbedaan posisi geografis dan maritim antar daerah di Indonesia yang sangat kuat dipengaruhi oleh sistem monsoon maupun pengaruh lokal yang membentuk pola hujan yang berbeda. Osok et al. (2017) menyatakan bahwa pada tahun tertentu pengaruh El Nino kuat di wilayah tertentu dan lemah di wilayah lainnya; bahkan 
pada tahun tertentu kejadian ini bisa terjadi di suatu wilayah tetapi tidak terjadi di wilayah lainnya. Kejadian curah hujan di bawah normal (kekeringan) dan fenomena El Nino tersebut memberikan gambaran bahwa kejadian kekeringan di Pulau Kei Kecil tidak selalu bersamaan dengan kejadian El Nino; dan kejadian El Nino tidak selalu menyebabkan kekeringan atau curah hujan di bawah normal. Selanjutnya, tahun 1994, 2009, 2014, dan 2018 tercatat sebagai tahuntahun El Nino tetapi tidak menyebabkan kekeringan atau curah hujan di Pulau Kei Kecil di bawah kondisi normalnya.

Tabel 1. Curah hujan selama tiga tahun kejadian El-Nino dengan intensitas kuat di Pulau Kei Kecil selama 30 tahun periode 1989-2018

\begin{tabular}{|c|c|c|c|c|c|c|c|c|c|c|c|c|c|}
\hline \multirow{2}{*}{ Tahun } & \multicolumn{13}{|c|}{ Curah Hujan (mm) } \\
\hline & Jan & Feb & Mar & Apr & Mei & Jun & Jul & Ags & Sep & Okt & Nov & Des & Setahun \\
\hline 1991 & 486 & 166 & 217 & 328 & 43 & 66 & 78 & 24 & 0 & 58 & 187 & 399 & 2052 \\
\hline 1997 & 269 & 678 & 81 & 166 & 36 & 12 & 96 & 0 & 0 & 0 & 80 & 445 & 1863 \\
\hline 2015 & 520 & 410 & 334 & 231 & 77 & 138 & 27 & 3 & 0 & 0 & 43 & 335 & 2118 \\
\hline $\begin{array}{c}\text { Rata- } \\
\text { rata }\end{array}$ & 425 & 418 & 211 & 242 & 52 & 72 & 67 & 9 & 0 & 19 & 103 & 393 & 2011 \\
\hline $\begin{array}{l}\text { Normal } \\
\text { (Rata- } \\
\text { rata) }\end{array}$ & 410 & 338 & 335 & 307 & 231 & 201 & 115 & 57 & 59 & 88 & 174 & 401 & 2716 \\
\hline
\end{tabular}

Penyimpangan dari kondisi normal

\begin{tabular}{cccccccccccccccc}
$\mathrm{Mm}$ & 15 & 80 & -125 & -66 & -179 & -129 & -48 & -48 & -59 & -68 & -71 & -8 & -705 \\
$\%$ & 4 & 24 & -37 & -21 & -77 & -64 & -42 & -84 & -100 & -78 & -41 & -2 & -26 & \\
\hline
\end{tabular}

Tabel 1 menunjukkan bahwa pada kondisi ekstrem El-Nino penurunan curah hujan dari kondisi normalnya terjadi selama setahun sebesar $705 \mathrm{~mm}$ atau 26\% dari kondisi normalnya. Penurunan curah hujan akibat El Nino yang yang dimulai sejak bulan Maret hingga November berlangsung tiap bulannya sebesar 48-179 mm per bulan atau 21$100 \%$ dari kondisi normalnya. Presentase penurunan terbesar berlangsung dalam bulan Agustus hingga Oktober dengan kisaran 78-100\%. Ini sesuai dengan Hidayat dan Ando (2014) yang mengemukakan bahwa dampak El Nino terhadap penurunan curah hujan di sebagian besar wilayah Indonesia terlihat dominan pada periode Juni-November. Sementara itu, periode Desember-Mei relatif tidak memberikan pengaruh yang berarti terhadap penurunan curah hujan. Bulan Agustus, September, dan Oktober merupakan bulan-bulan dengan resiko kekeringan yang paling besar ketika El Nino berlangsung; dimana curah hujan bulanannya $<20 \mathrm{~mm}$. Curah hujan yang kurang dari $20 \mathrm{~mm}$ per bulan akan menimbulkan cekaman air bagi tanaman yang sumber airnya hanya dari hujan. Banyak literatur dan pendapat ahli di antaranya oleh Schmidt-Ferguson (1951) dan Oldeman (1975) menyatakan bahwa curah hujan yang ideal untuk tanaman umur panjang minimal $60 \mathrm{~mm}$ per bulan, sedangkan untuk tanaman semusim atau umur pendek minimal 100 mm per bulan.

\section{Musim Tanam}

Tabel 2.

Hasil penentuan musim tanam di Pulau Kei Kecil pada dua kondisi curah hujan seperti yang ditunjukkan pada

Hasil analisis musim tanam pada Tabel 2 tersebut menunjukkan bahwa musim tanam di Pulau Kei Kecil pada kondisi curah hujan rata-rata (normal) berlangsung selama 289 hari (1 November sampai dengan 16 Agustus; 9 bulan 16 hari); sedangkan musim tanam ketika curah hujan ekstrim El Nino berlangsung selama 201 hari (1 November sampai dengan 20 Mei; 6 bulan 20 hari). Hal ini mengindikasikan bahwa ketika El Nino berlangsung di Pulau Kei Kecil, akan terjadi pergeseran musim tanam (berakhir lebih cepat) selama 88 hari atau sekitar 3 bulan, dibandingkan musim tanam normalnya. Artinya, akhir musim tanam ketika terjadi El Nino berlangsung lebih cepat; hal ini terutama disebabkan oleh berkurangnya curah hujan yang cukup tajam dalam periode Mei-Juli, yaitu 42-77\% dari curah hujan normalnya.

Dampak lanjutan dari musim tanam yang lebih pendek akibat El Nino ini adalah berkurangnya intensitas tanam (terutama tanaman semusim berumur 3 bulan), selanjutnya ini berdampak lebih lanjut terhadap berkurangnya luas panen dan akhirnya bermuara pada berkurangnya produksi tanaman per tahunnya. 
Tabel 2. Penetuan musim tanam di Pulau Kei Kecil pada dua kondisi curah hujan

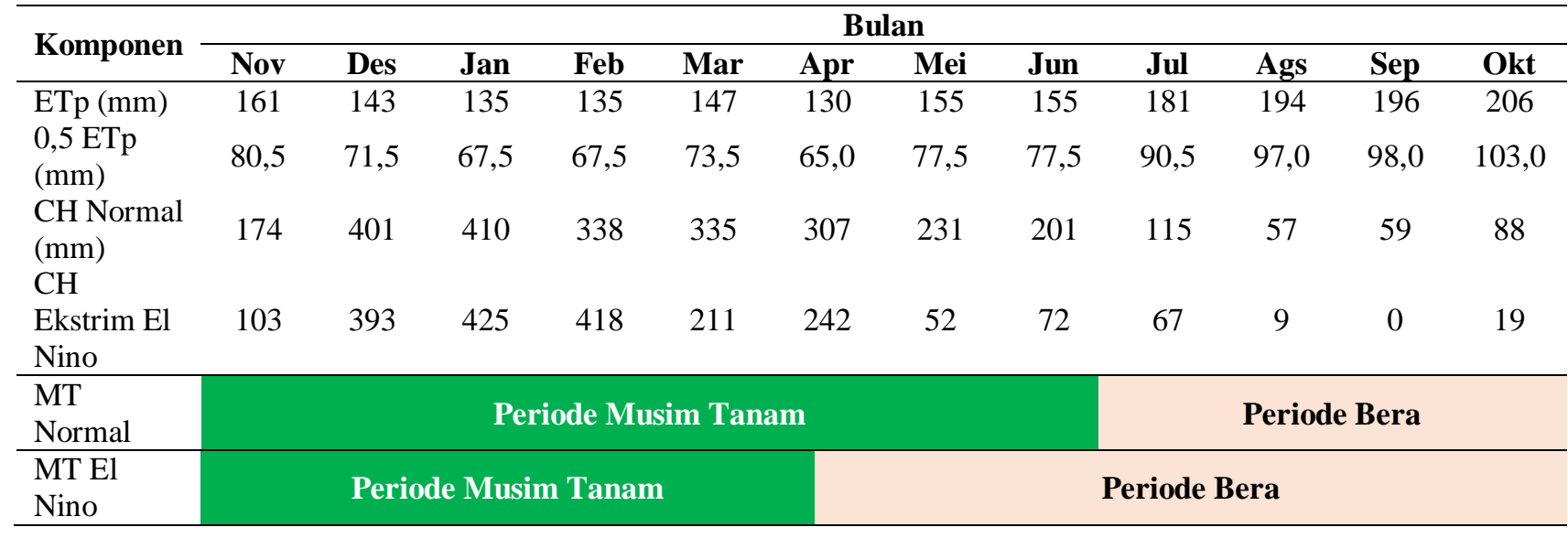

Keterangan: $\mathrm{ETp}=$ evapotraspirasi potensial; $\mathrm{CH}=$ curah hujan; $\mathrm{MT}=$ musim tanam.

\section{Produktivitas Kacang Tanah}

Data pada Tabel 3 menunjukkan bahwa produktivitas kacang tanah di Pulau Kecil berkisar antara 228 sampai $668 \mathrm{~kg}$ biji kering per ha, dengan rata-rata $515 \mathrm{~kg}$ biji kering per ha. Merujuk pada data BPS (2019), nilai produktivitas kacang tanah di Pulau Kei Kecil lebih rendah dibandingkan dengan data produksi nasional maupun Provinsi Maluku, yaitu masing-masing $1.323 \mathrm{~kg}$ per ha dan $982 \mathrm{~kg}$ per ha. Melalui wawancara yang mendalam dengan petani diperoleh informasi/data rata-rata produksi dan produktivitas kacang tanah dalam 5 tahun terakhir, yaitu periode 2014-2018. Kacang tanah biasanya ditanam 2 kali dalam setahun, yaitu masa tanam I: Januari-Maret atau Februari-April dan masa tanam II: Mei-Juli. Menurut petani pada kondisi curah hujan normal, produksi kacang tanah lebih tinggi pada masa tanam II dibandingkan dengan masa tanam I. Rendahnya produksi, tidak menentu dan bahkan kadang-kadang gagal panen pada masa tanam I terutama disebabkan akibat curah hujan yang tinggi.

Tabel 3. Produktivitas kacang tanah di Pulau Kei Kecil pada periode 2014-2018

\begin{tabular}{cccc}
\hline Tahun & Luas Panen*) (ha) & $\begin{array}{c}\text { Produksi } \\
\text { biji kering }(\mathrm{kg})\end{array}$ & $\begin{array}{c}\text { Produktivitas } \\
\text { (kg biji kering/ha) }\end{array}$ \\
\hline 2014 & 0,202 & 100 & 495 \\
2015 & 0,202 & 46 & 228 \\
2016 & 0,202 & 121 & 597 \\
2017 & 0,202 & 135 & 668 \\
2018 & 0,202 & 119 & 589 \\
\hline
\end{tabular}

\section{Dampak El Nino Terhadap Produktivitas Kacang Tanah}

Untuk melihat hubungan antara curah hujan dan produktivitas kacang tanah digunakan data seperti yang ditunjukkan pada Tabel 4.

Tabel 4. Curah hujan dan prododuktivitas kacang tanah di Pulau Kei Kecil periode 2014-2018

\begin{tabular}{ccc}
\hline Tahun & $\begin{array}{c}\text { Curah Hujan Periode Mei-Juli } \\
(\mathrm{mm})\end{array}$ & $\begin{array}{c}\text { Produktivitas (kg biji } \\
\text { kering per ha) }\end{array}$ \\
\hline 2014 & 560 & 495 \\
2015 & 242 & 228 \\
2016 & 726 & 597 \\
2017 & 744 & 668 \\
2018 & 541 & 589 \\
\hline
\end{tabular}


Berdasarkan hasil analisis regresi yang melihat hubungan antara curah hujan dengan produktivitas tanaman kacang tanah, diperoleh persamaan: $\mathrm{Y}=60,73+0.8082 \mathrm{X}$ (Gambar 2); dengan nilai koefisien korelasi (r) sebesar 0.9479. Persamaan ini menggambarkan bahwa penigkatan nilai curah hujan (X) akan menigkatkan produktivitas tanaman kacang tanah (Y).

Nilai koefisien determinasi $\left(\mathrm{R}^{2}\right)$ adalah sebesar $89.9 \%$, yang memberi gambaran bahwa pengaruh dependent variable (variabel tak-bebas; perubahan curah hujan) dapat menjelaskan independent variable (variable bebas; produktivitas tanaman kacang tanah) sebesar $89.9 \%$, sisanya 10,1\% dari produktivitas tanaman kacang tanah dijelaskan oleh variabel lain yang tidak dimasukkan dalam model. Nilai koefisien b memberi gambaran bahwa jika terjadi penambahan 1 satuan curah hujan maka diramalkan terjadi peningkatan produktivitas kacang tanah sebsar $0.8082 \mathrm{~kg}$ per ha.

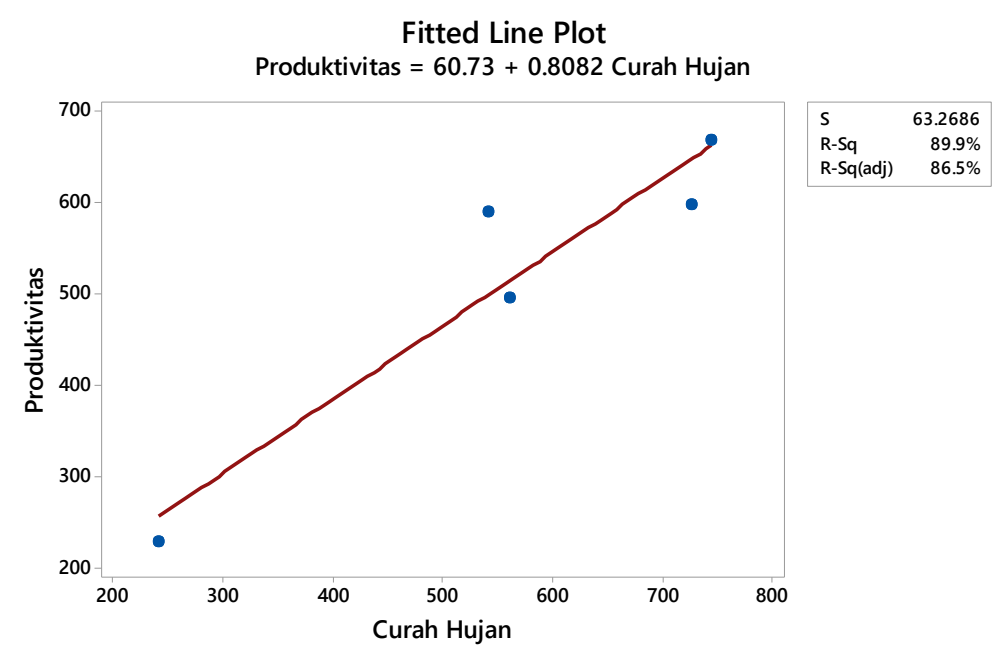

Gambar 2. Grafik hubungan curah hujan dengan produktivitas kacang tanah di Pulau Kei Kecil

Jika Gambar 2 dikaitkan dengan data Tabel 4, diketahui bahwa kejadian El Nino tahun 2015 yang diindikasikan oleh curah hujan yang rendah selama periode masa tanam II, yaitu hanya sebesar $242 \mathrm{~mm}$, menyebabkan produktivitas kacang tanah juga rendah, yaitu hanya sebesar $228 \mathrm{~kg}$ per ha. Curah hujan yang rendah tersebut tidak mencukupi kebutuhan air tanaman kacang tanah mulai tanam hingga panen; terutama pada fase perkembangan kacang tanah yang sensitif terhadap kekurangan air. Pada periode musim tanam II di Pulau Kei Kecil, yang terjadi adalah: 1) curah hujan selama musim tanam ketika El Nino $(224 \mathrm{~mm})$ masih jauh di bawah kebutuhan air tanaman kacang tanah untuk tumbuh dan berproduksi secara baik yang berkisar antara 342-831 mm, 2) curah hujan pada bulan ke-2 dan ke-3 dimana kacang tanah berada pada fase sensitif terhadap kekurangan air hanya sebesar $163 \mathrm{~mm}$; nilai ini dianggap jauh di bawah kebutuhan air tanaman (minimal $100 \mathrm{~mm}$ per bulan menurut Oldeman, 1975), sehingga menyebabkan pertumbuhan tanaman kacang tanah terhambat selama fase tersebut hingga berujung pada rendahnya produksi dan produktivitas tanaman kacang tanah.

\section{KESIMPULAN}

Kesimpulan-kesimpulan hari hasil penelitian ini adalah sebagai berikut:

1. Berdasarkan data curah hujan selama 30 tahun (periode 1989-2018), kejadian El Nino di Pulau Kei Kecil berlangsung sebanyak 6 kali, yaitu pada tahun: 1991, 1997, 2002, 2004, 2006 dan 2015 dengan frekuensi 2-9 tahun sekali atau rata-rata 5 tahun sekali.

2. Pada kondisi curah hujan normal, musim tanam di Pulau Kei Kecil berlangsung selama 9 bulan 16 hari, dari 1 November hingga 16 Agustus (289 hari). Ketika terjadi El-Nino, musim tanam menjadi pendek atau berakhir lebih cepat, yaitu hanya 201 hari, dari 1 November hingga 20 Mei atau 6 bulan 20 hari.

3. Penurunan curah hujan ketika El Nino berpengaruh sangat nyata terhadap penurunan produktivitas kacang tanah atau memiliki keeratan hubungan yang kuat, yang ditunjukkan oleh nilai koefisien korelasi $\mathrm{r}=0,9479$ dan tingkat akurasi yang tinggi dengan $\mathrm{R}^{2}=89,9 \%$. 


\section{DAFTAR PUSTAKA}

Badan Pusat Statistik (BPS). 2019. Provinsi Maluku Angka. BPS Provinsi Maluku, Ambon.

Food Agriculture Organization (FAO). 1978. Methodology and results from Africa. Report on the Agro-Ecological Zones Project. Report No.48/I. FAO, Rome.

Hidayat, R dan K. Ando. 2014. Variabilitas curah hujan Indonesia dan hubungannya dengan ENSO/IOD: Estimasi menggunakan data JRA-25/JCDAS. Jurnal Agromet 28(1): 1-8. ISSN: 0126-3633. DOI: https://doi.org/10.29244/j.agromet.28.1.1-8.

Irianto, G dan Suciantini. 2006. Anomali iklim: faktor penyebab, karakteristik, dan antisipasinya. Jurnal IPTEK Tanaman Pangan 1(2):101-121. ISSN: 1907-4263. http://ejurnal.litbang.pertanian.go.id/index.php/ippan/article/view/2675.

Laimeheriwa, S. 2014. Analisis tren perubahan curah hujan pada tiga wilayah dengan pola hujan yang berbeda di Provinsi Maluku. Jurnal Budidaya Pertanian 10(2):71-78. ISSN: 1858-4322.

Laimeheriwa, S., M. Pangaribuan dan M. Amba. 2019. Analisis fenomena El Nino dan dampaknya terhadap neraca air lahan di Pulau Ambon. Jurnal Budidaya Pertanian 15(2):111-118. DOI: https://doi.org/10.30598/jbdp.2019.15.2.111.

Las, I. 2006. Strategi dan teknologi antisipasi dan penanggulangan bencana iklim (kejadian iklim ekstrim). Balai Besar Sumberdaya Lahan Pertanian. Makalah disampaikan pada Pelatihan Capable, Juli 2006. Biotrop, Bogor.

Nangimah, S.L., S. Laimeheriwa, dan R. Tomasoa. 2018. Dampak fenomena El Nino dan La Nina terhadap keseimbangan air lahan pertanian dan periode tumbuh tersedia di Daerah Waeapo Pulau Buru. Jurnal Budidaya Pertanian 14(2):66-74. DOI: https://doi.org/10.30598/jbdp.2018.14.2.66.

National Oceanic and Atmospheric Administration_USA (NOAA). 2019. Oceanic Nino Index (ONI): ENSO History Zone NINO 3.4. http://www.cpc.noaa. gov/, diakses 11 Mei 2021.

Oldeman, L.R. 1975. An Agroclimatic Map of Java. Contr. Centr. Res. Inst. Agric., 17, Bogor. 22p+map.

Osok, R.M., P.J. Kunu dan S. Laimeheriwa. 2017. Kajian dampak perubahan iklim terhadap ketersediaan air di Pulau Wamar Kabupaten Kepulauan Aru. Laporan Penelitian, Kerjasama dengan USAID, Jakarta.

Schmidt, F.H. dan H.A. Ferguson. 1951. Rainfall Types Based on Wet and Dry Period Ratios for Indonesia with Western New Guinea. Kementerian DMG-Perhubungan, Jakarta.

Sitaniapessy, P.M. 2002. Problema lingkungan pulau kecil di Maluku. Jurnal Pertanian Kepulauan 1(2): 79-8. 